\section{Anatomy and histochemistry of the vegetative organs of Cissus verticillata - a native medicinal plant of the Brazilian Amazon}

\author{
Andréia B. de Oliveira, ${ }^{1}$ Maria S. de Mendonça, ${ }^{1}$ Aristea A. \\ Azevedo, ${ }^{2}$ Renata M. S. A. Meira ${ }^{*, 2}$
}

${ }^{1}$ Laboratório de Botânica Agroflorestal, Universidade Federal do Amazonas, Brazil, ${ }^{2}$ Laboratorio de Anatomia Vegetal, Universidade Federal de Viçosa, Brazil.

\begin{abstract}
The purpose of this paper was to carry out an anatomical and histochemical analysis of the vegetative organs of Cissus verticillata (L.) Nicolson \& C.E. Jarvis, Vitaceae, to contribute for the attest the taxonomic identity of the medicinal plant. Samples from root, stem, leaf and tendril were cleared, dissociated and processed according to the usual methodology for observation under light and scanning electron microscopes. Histochemical tests were performed in order to identify polysaccharides, phenolic and lipid compounds. The $C$. verticillata root is typically protostelic, and the stem is eustelic with collateral bundles. The tendril presents structural organization similar to the stem, suggesting a common origin for both. The petiole has an epidermis with ornamented cuticle; the cortex is composed of collenchyma and parenchyma, and the vascular tissues are arranged in collateral bundles. The leaf blade is amphistomatic with non-glandular and glandular trichomes, and the mesophyll is dorsiventral. The identification of the idioblasts as secretion site of the phenolic compounds, mucilage and terpenoids as being responsible for the potential activity of the plant is of fundamental importance for future bioprospecting research on this species.
\end{abstract}

Revista Brasileira de Farmacognosia Brazilian Journal of Pharmacognosy 22(6): 1201-1211, Nov./Dec. 2012

Article

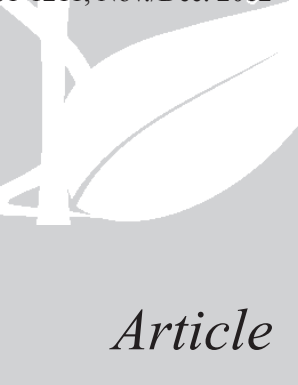

Received 3 Nov 2012

Accepted 1 Jun 2012

Available online 17 Jul 2012

Keywords: anatomy secondary metabolites vegetal insulin Vitaceae

ISSN 0102-695X http://dx.doi.org/10.1590/S0102$695 \mathrm{X} 2012005000053$

\section{Introduction}

Vitaceae is represented by four genera, with approximately eighty species comprising the genus Cissus (Lombardi, 2007). Cissus verticillata (L.) Nicolson \& C. E. Jarvis, Vitaceae, is a vine that grows spontaneously in various regions of the Brazil. It occurs in disturbed areas, creeping over other plants. It is generally found in sunny environments and near watercourses (Berg, 1993; Lorenzi, 2008).

This species has been studied in the areas of Pharmacology, Health Science and Phytochemistry, as a potential medicinal plant, used in the treatment of diabetes mellitus type 2 (Garcia et al., 1997; Garcia et al., 2000; Beltrame et al., 2001; Barbosa et al., 2002; Pepato et al., 2003; Viana et al., 2004; Almeida et al., 2006; Silva et al., 2007; Braga, 2008). The effectiveness of the plant as an anti-inflammatory, antiepileptic, antihypertensive, antipyretic and antirheumatic has also been emphasized (Garcia et al., 2000; Almeida et al., 2006; Braga, 2008). Phytochemical data showed that leaves of $C$. verticillata contain: tannins, reducer compounds, steroids and triterpenes, aminoacids, fatty compounds and flavonoids, more specifically, kaempferol, luteolin and luteolin-3'-sulfate, which are all related to the biological activity of the plant (Lizama et al., 2000; Barbosa et al., 2002).

Aspects related to the morphology and anatomy of $C$. verticillata are found in studies on the Vitaceae family e.g. the works of Solereder (1908) and Metcalfe \& Chalk (1957), and in more specific works, such that of Lizama et al (2000) on the leaf blade anatomy of $C$. verticillata. Some anatomical characters of the stem, such as the presence of a starch sheath, secretory cavities, and fibers containing starch grains, and the presence and type of trichomes, were highlighted as important for the taxonomy of C. spinosa Cambessedes, C. ulmifolia (Baker) Planchon, C. erosa Richard and C. sicyoides L. (Alquini et al., 1995). On the abaxial face of the leaves of the $C$. verticillata occur secretory structures which have been described as pearl glands or pearl bodies. These structures have been recently studied and constitute food bodies (Paiva et al., 2009).

Given that the anatomy is an important taxonomic parameter for the certification and quality control of medicinal plants, and for the localization of secretion and/or accumulation sites of biologically active compounds, it is necessary to investigate the vegetative organs of species with therapeutic potential. The present paper characterizes the vegetative organs of 
C. verticillata, both anatomically and histochemically.

\section{Materials and Methods}

For the anatomical characterization, botanical material was collected from plants growing spontaneously in the campus of the Federal University of Amazonas $\left(03^{\circ}\right.$ $05^{\prime} 41^{\prime \prime} \mathrm{S}$ and $59^{\circ} 59^{\prime} 10^{\prime \prime} \mathrm{W}$, altitude of $77 \mathrm{~m}$ ). For the histochemical analysis, fresh samples were obtained from plants cultivated in gardens of the Federal University of Viçosa $\left(20^{\circ} 45^{\prime} 24^{\prime \prime} \mathrm{S}\right.$ and $42^{\circ} 52^{\prime} 22^{\prime \prime} \mathrm{W}$, altitude of 680 $\mathrm{m})$.

Stem, tendril and leaf (petiole and blade) samples from six individuals of Cissus verticillata (L.) Nicolson \& C.E. Jarvis, Vitaceae, were collected, from the region between the $8^{\text {th }}$ and the $10^{\text {th }}$ nodesof the branch apex. Cylinders of about $20 \mathrm{~mm}$ in length were removed from the internode portion of the stem (above the 10th branch node), and older portions were obtained from the plant base. Root fragments of approximately $30 \mathrm{~mm}$ in length, were obtained from the subapical and proximal portions of plants obtained from cuttings kept in a greenhouse at the UFAM. Voucher specimens were deposited in the Herbarium of the National Institute Research in the Amazon (INPA214753) and in the VIC Herbarium of the Federal University of Viçosa (UFV30363).

For the anatomical evaluations, the samples were fixed for $48 \mathrm{~h}$ in neutral-buffered formaldehyde solution and then stored in 70\% ethanol (Kraus \& Arduin, 1997). The dissociation of the epidermis in $100 \mathrm{~mm}^{2}$ sections, from the apical, middle and basal portions of the leaf blade, including the midrib and margin, was performed with Jeffrey's solution (Johansen, 1940 modified). Fragments of abaxial and adaxial surface were stained with safranina and astra blue (Kraus \& Arduin, 1997) and mounted on slides with glycerol jelly (Johansen, 1940).

Samples of the vegetative organs were dehydrated in ethylic series (70\%-95\%), and embedded in methacrylate (Historesin Leica ${ }^{\circledR}$ ). Sections of 7-8 $\mu \mathrm{m}$ were obtained with an automatic advanced rotary microtome (RM 2155, Leica ${ }^{\circledR}$ ), stained with toluidine blue pH 4.4 (O'Brien \& McCully, 1981) and mounted on slides with synthetic resin (Permount-Fisher ${ }^{\circledR}$ ).

The histochemical tests were performed using transversal sections of fresh samples of leaves, stems and roots. The reagents used were: ruthenium red to detect pectin and mucilage (Johansen, 1940); Lugol's iodine solution for starch (Jensen, 1962); potassium dichromate at 10\% forphenolic compounds (Gabe, 1968); hydrochloric vanillin for tannins (Mace \& Howell, 1974); Sudan IV for total lipids (Brundett el al., 1991) and Nadi reagent for terpenoids (David \& Carde, 1964). Control sections were performed simultaneously.

Part of the histological methacrylate sections was submitted to xylidine ponceau (XP pH 2.5) to detect total proteins (O'Brien \& McCully, 1981). PAS (periodic acidSchiff's reagent) to detect polysaccharides (Maia, 1979), both mounted on slides with synthetic resin (Permount).

The images were recorded on a photonic microscope (model AX 70 TRF, Olympus Optical) with U-PHOTO system, equipped with a video camera and a microcomputer with image analyzer (Image Pro-Plus).

To describe the surface characters of the leaf blade, some of the fixed samples were subdivided into small pieces $\left(100 \mathrm{~mm}^{2}\right)$, dehydrated in ethylic series then dried to carbon dioxide critical point (Bozzola \& Russel, 1992). After fixing the samples on the supports, metallic gold deposition was performed using Sputter Coater equipment (model FDU 010, Bal-Tec, Balzers, Germany). The images were obtained with a scanning electron microscope (model LEO 1430 VP, Zeiss, Cambridge, England).

The vascular bundle arrangement in the petiole was classified according to Howard (1979), the venation pattern and stomata type of the leaf blade were classified according to Metcalfe \& Chalk (1979) and the trichomes were analyzed according to the classification proposed by Theobald et al. 1979.

\section{Results}

The root in primary growth presents a uniseriate epidermis and cortex consisting of loosely arranged parenchyma cells, commonly with voluminous idioblasts that are notable because they containing droplets, and others containing raphides immersed in polysaccharide substances (Figure 1A-C). The cytoplasm of the endoderm cells is strongly stained (Figure 1A), with Caspary bands observable only in the fresh sections (Figure 1D). The vascular cylinder is organized in three protoxylem poles alternated with phloem, surrounded by the pericycle, in a typical protostelic structure (Figure 1A). Adventitious roots originating from the same individual present a parenchymatous pith, with starch reserve (Figure 1E).

In the secondary structure, the root periderm presents 3 to 4 strata of procumbent cells with suberified walls (Figure 1F-G) and pheloderm with rectangular to isodiametric cells (Figure 1F). The maintenance of the innermost layers of the cortex indicates a subepidermal origin of the phellogen (Figure 1F). The cortex presents cell strata of various sizes and few meatus (Figure 1E), with brachysclereids occurring in groups or individually (Figure 1G) and from one to multiple idioblasts containing druses or raphides (Figure 1E).

The vascular cylinder is surrounded by the pericycle, which presents two strata of parenchyma cells in secondary structure (Figure 1E). In longitudinal section, lateral roots originating from the pericycle activity were observed (Figure 1H). The vascular 
cambiumis composed of a continuous ring of cells with thin walls and wide rays, formed by erect parenchyma cells of various sizes, the cytoplasm of which is sometimes has a purple coloration (Figure 1E).

Starch grains were detected in the pith (Figure 2A). Secretory idioblasts were seen in the cortex and pith. Cytoplasmatic content was visible, stained pink by the PAS (Figure 2B) and red by the ruthenium red, showing the presence of polysaccharides and mucilage, respectively. In some of these mucilaginous idioblasts, raphides were also observed under polarized light (Figure 2C-D). Secretory idioblasts of compounds of diverse chemical compositions were observed in the cortex, by the reaction for phenolic compounds, tannins and essential oils (Figure 2E-G). No protein was detected in the idioblast secretion.
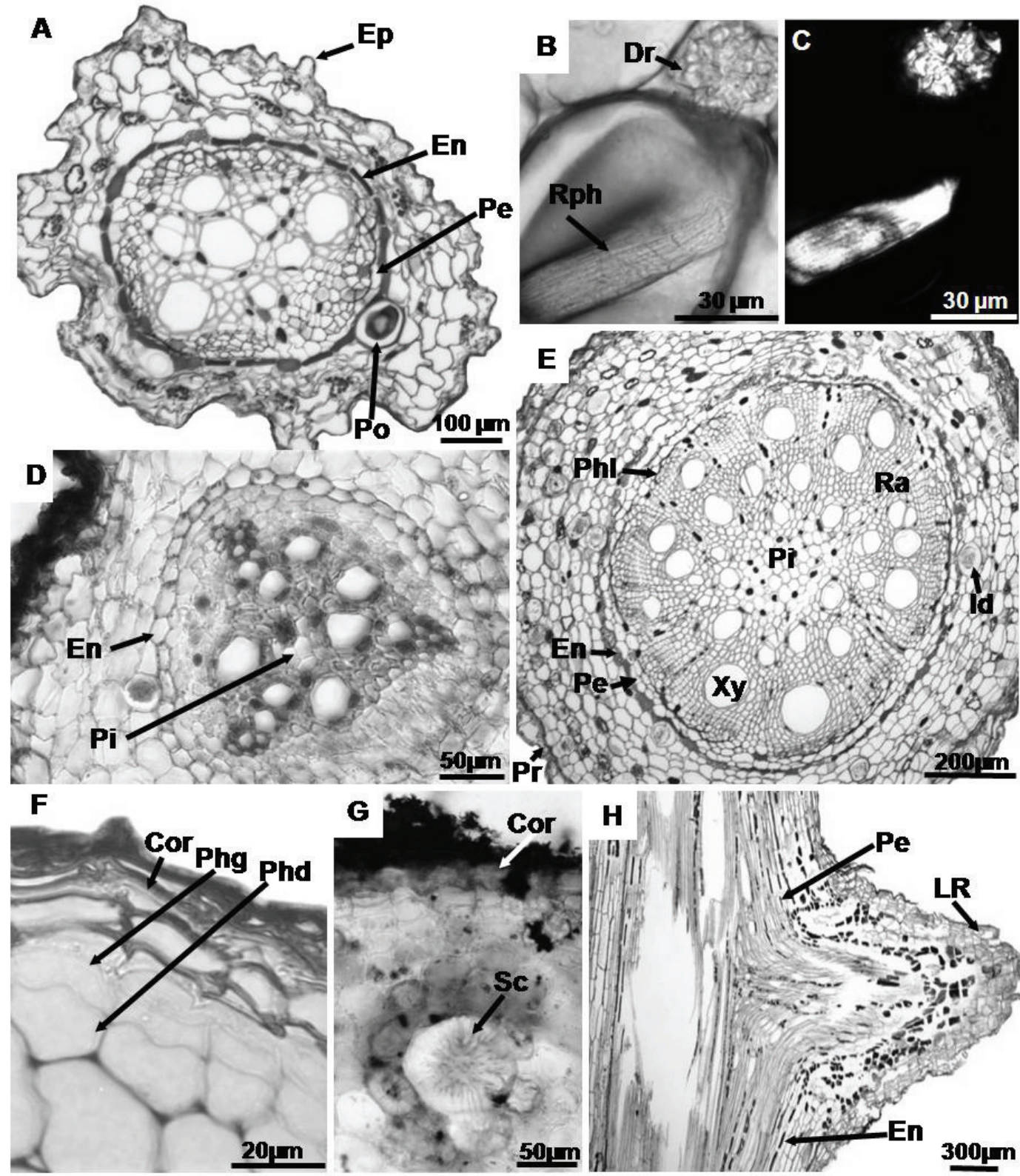

Figure 1. Cissus verticillata root structure (A-G, cross sections; H, longitudinal sections). A-D: primary structure; A. general appearance of the root; B. raphide and druse in the cortex; C. raphide and druse under polarized light; D. adventitious root with detail of the pith and endoderm; E-H: secondary structure; E. general aspect; F. periderm; G. periderm colored with sudan IV; H. lateral roots formation. (Dr, druse; En, endoderm; Ep, epidermis; Sc, sclereids; Phd, pheloderm; Phg, phellogen; Phl, phloem; Id, idioblast; Pi, pith; Pe, pericycle; Pr, periderm; Rph, raphide; Ra, rays; LR, lateral root; Po, polysaccharide with raphide; Cor, cork; Xy, xylem). 

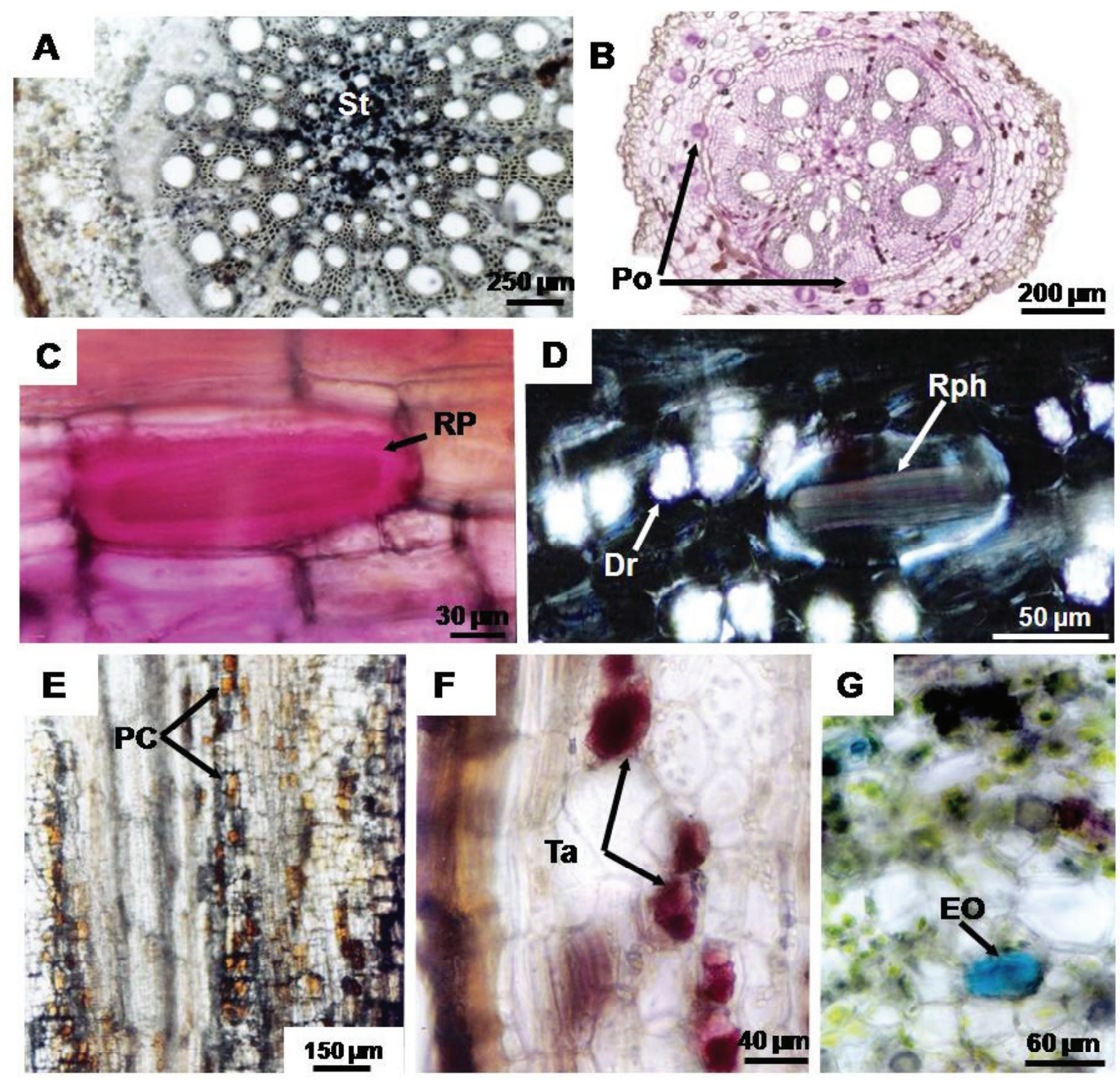

Figure 2. Cissus verticillata root structure (A-B, cross sections; C-G, longitudinal sections). A. starch evidenced by the Lugol's iodine solution; B. cortical details showing idoblasts with polysaccharide evidenced by the PAS; C. idioblast with raphide and polysaccharide content evidencing the ruthenium red; D. idioblast with druse, raphide and polysaccharide content evidencing the ruthenium red under polarized light; E. idioblast with phenolic compound evidenced by the potassium dichromate; F. idioblast with tannin evidenced by the vanillin hydrochroride; G. idioblast with essential oil evidenced by the Nadi. (St, starch; Po, polysaccharide; RP, raphide and polysaccharide content; Dr, druse; Rph, raphide; PC, phenolic compound; Ta, tannin; EO, essential oil).

The stem in primary structure (Figure $3 \mathrm{~A}$ ) has an epidermis with a layer of generally subpapillose cells covered by striated cuticle (Figure 3B). The subepidermal cells of the cortex initiate the meristematic activity, giving rise to the phellogen (Figure 3C). The cortex consists of layers of parenchyma cells, which are interrupted by annular collenchyma strands (Figure 3B).

In secondary structure, the stem presents a periderm with smooth surface and lenticels (Figure
3D, 3G). The cortex is still narrow, with compact parenchyma tissue and brachysclereid clusters (Figure $3 \mathrm{E}$ ). The rays are two or more cells range (Figure 3D, $3 \mathrm{~F}$ ), formed by parenchyma cells, sometimes with strongly stained, dense cytoplasm. Idioblasts containing monocrystals are dispersed in this tissue (Figure 4B), druses and raphides or raphide embedded in polysaccharide (Figure 4C-E). The axial parenchyma is distributed around xylematic fiber strands surrounding the vessel elements (Figure 3F, 4C), and some of these 
cells contain calcium oxalate crystals.

The vessel elements are solitary, pitted type with a simple perforation plate. In many of these elements, tyloses were also observed (Figure 3F, 4A, 4C). Cells of the xylem parenchyma may contain substances that are released and distributed in the event of injury (Figure 4C). Parenchyma tissue occurs in the pith, where secretory idioblasts, similar to those described for the root, are dispersed among the cells of this tissue (Figure 4C).
Regarding the cellular content, polysaccharide was detected in the idioblasts of the cortex and in the rays of the secondary xylem (Figure 4D-E). Starch grains were detected in the medullary parenchyma (Figure 4F). The test for total proteins was negative.

The tendril is covered by a uniseriate epidermis, composed of subpapillary cells with ornamented cuticle (Figure 5A). Within the epidermis there are two thinned-walled rectangular cells strata, with sporadic druses. The remainder of the cortex, the vascular
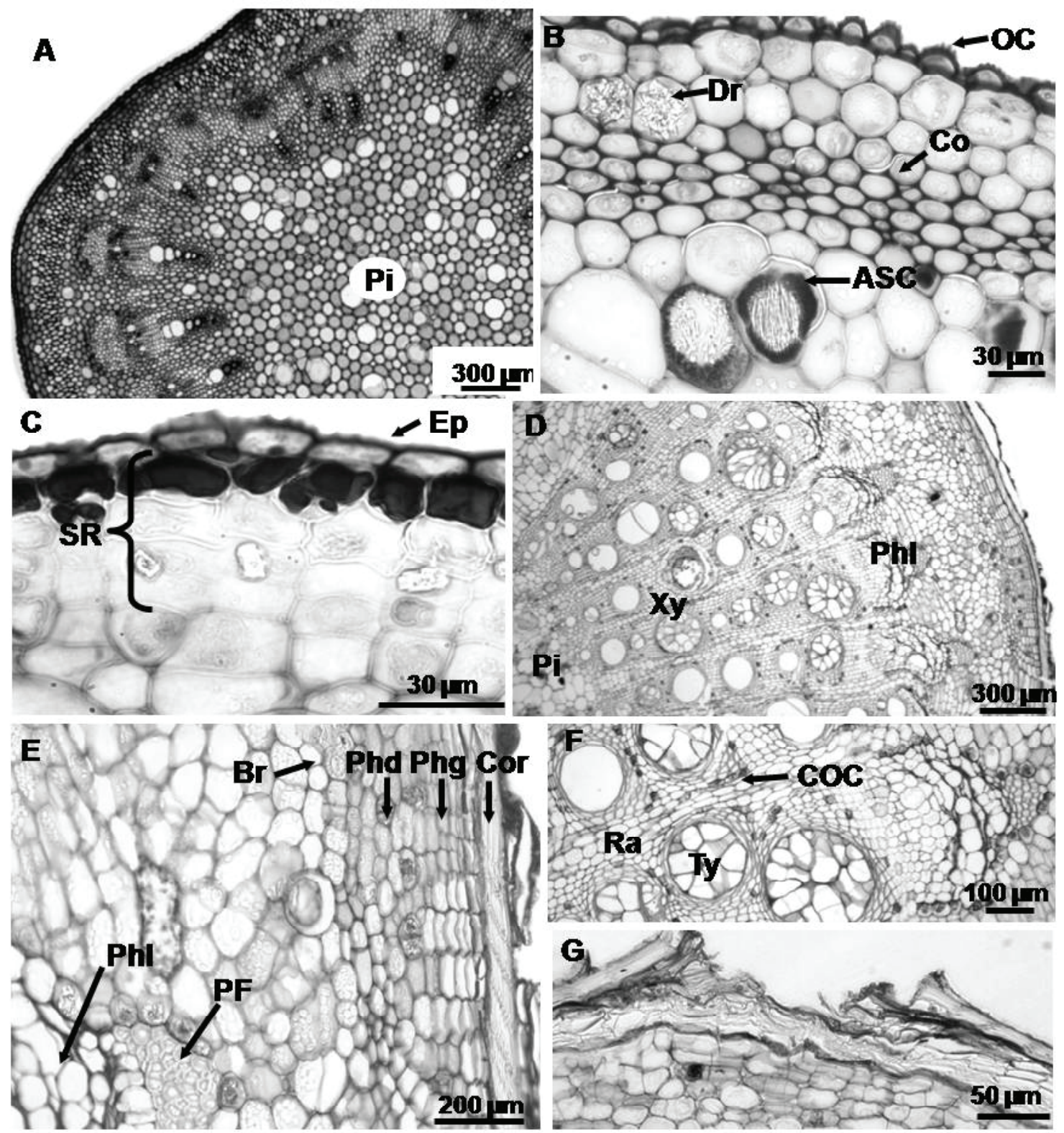

Figure 3. Cissus verticillata stem structure. (cross sections). A-C: primary structure; A. general aspect; B. epiderm and cortex, notice the collenchyma and the crystals; C. epiderm evidencing the subepidermal portion; D-F: secondary structure; D. general aspect; E. periderm and cortex; F. xylem with detail for tylosis; G. periderm with lenticels. (Br, brachysclereids; Co, collenchyma; COC, calcium oxalate crystals; OC, ornamented cuticle; Dr, druse; Ep, epiderm; Phd, pheloderm; Phg, phelogen; PF, phloem fibers; Phl, phloem; Pi, pith; Ra, rays; SR, subepidermal region; ASC, amorphous substance and crystal; Cor, cork; Ty, tylosis; Xy, xylem). 
bundles and the pith (Figure 5A) are organized like to that described for the stem primary structure, including the occurrence of crystals. The histochemical tests carried out revealed the presence of polysaccharides in the idioblasts, dispersed throughout the pith of this organ, and the absence of proteins.

The petiole is convex concave in shape (Figure 5B) and approximately $42 \mathrm{~mm}$ in length. The petiole epidermis is uniseriate with ornamented cuticle (Figure
5C). In the subepidermal portion, there are two or three strata of densely arranged homogeneous chlorophyll parenchyma (Figure 5C). Underlying this parenchyma, there is a continuous ring of angular collenchyma (Figure $5 \mathrm{~B}, 5 \mathrm{D})$.

The petiole presents about eleven collateral vascular bundles, forming parenchyma pith. Idioblasts containing polysaccharide occur in the pith and around the vascular bundles. Crystalliferous idioblasts occur

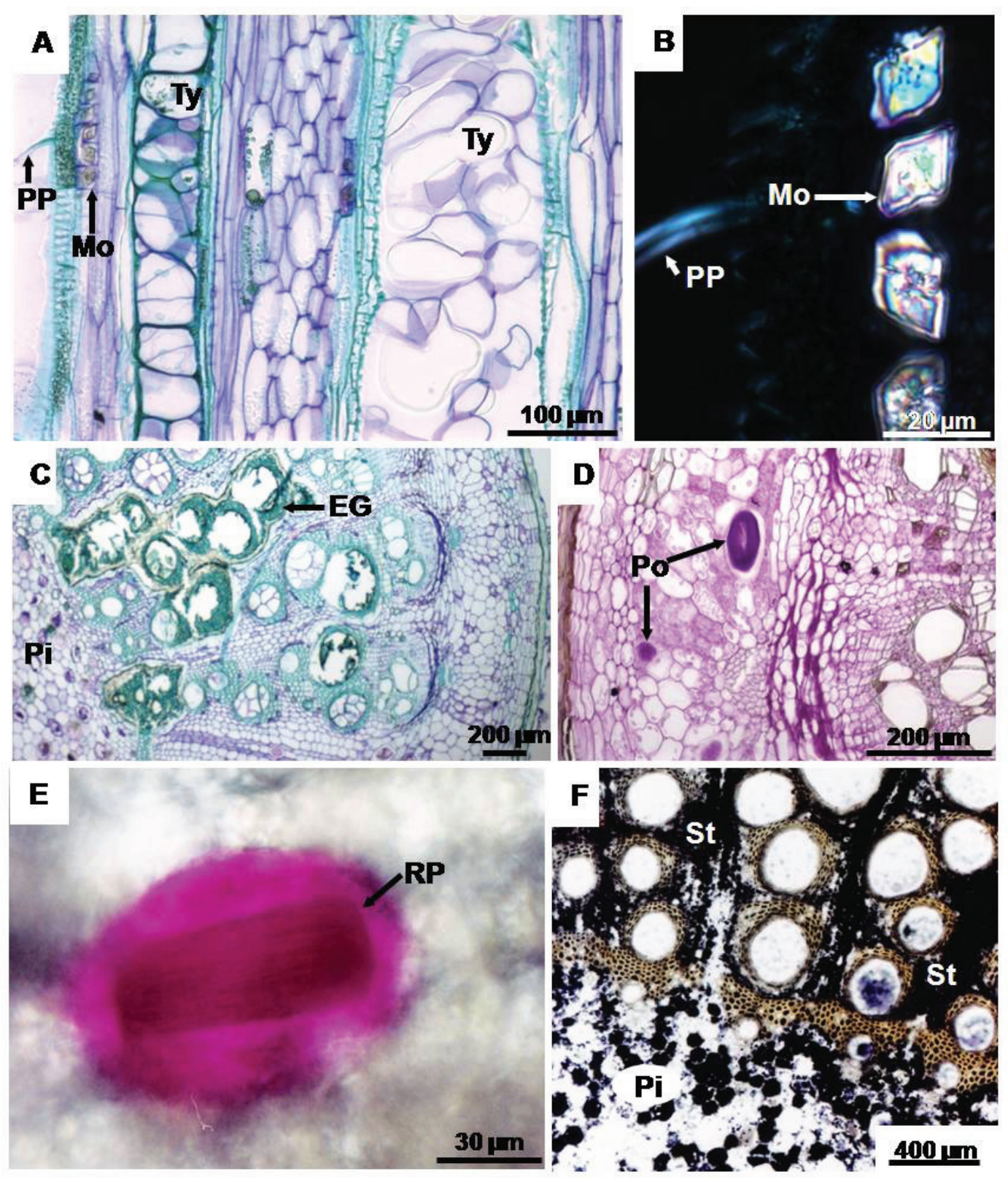

Figure 4. Cissus verticillata stem secondary structure. (A-B: longitudinal sections; C-F: cross sections). A. vessel element with tylosis; B. monocrystals under polarized light; C. vascular system, notice the accumulation of secretion (similar to gummosis); D. cortical details showing idioblast with polysaccharide content evidenced by the PAS; E. idioblast, in the rays, with raphide and polysaccharide content evidencing the ruthenium red; F. starch detected by the Lugol's iodine solution. (St, starch; EG, event to the gummosis; Pi, pith; Mo, monocrystals; Po, polysaccharide; PP, perforation plate; RP, raphide and polysaccharide content; Ty, tylosis). 
in the petiole, similar to those described above for the root and stem (Figure 5B).

The leaf is amphistomatic with stomata of the anomocytic type and striated cuticle covering the stomatal complex cells $(5 \mathrm{G})$. Multicellular and uniseriate non-glandular trichomes are present in the ribs and margin of both leaf surfaces $(5 \mathrm{~F}, 5 \mathrm{G})$. There is a multicellular glandular structure on the abaxial side of the leaf closer the central rib (Figures 6A, 6B).

The leaf blade has a uniseriate epidermis, with juxtaposed cells withthin, smooth walls and ornamented cuticle (Figure 5E). The epidermal cells from the adaxial surface are bigger, with ticker periclinal walls and with polygonal shape (Figure 5E). On the adaxial surface, the epidermal cells are covered a crystalline epicuticular wax pattern (Figure 5G).

The mesophyll is dorsiventral, consisting of one layer of palisade parenchyma, followed by four to five strata of spongy parenchyma with reduced meatus (Figure 5E). Secretory idioblasts, similar to those described for roots and stems, occur in the middle of the mesophyll close to the vascular bundles (Figure 5E). In the central midrib, there are angular collenchyma with approximately six layers, located underneath adaxial
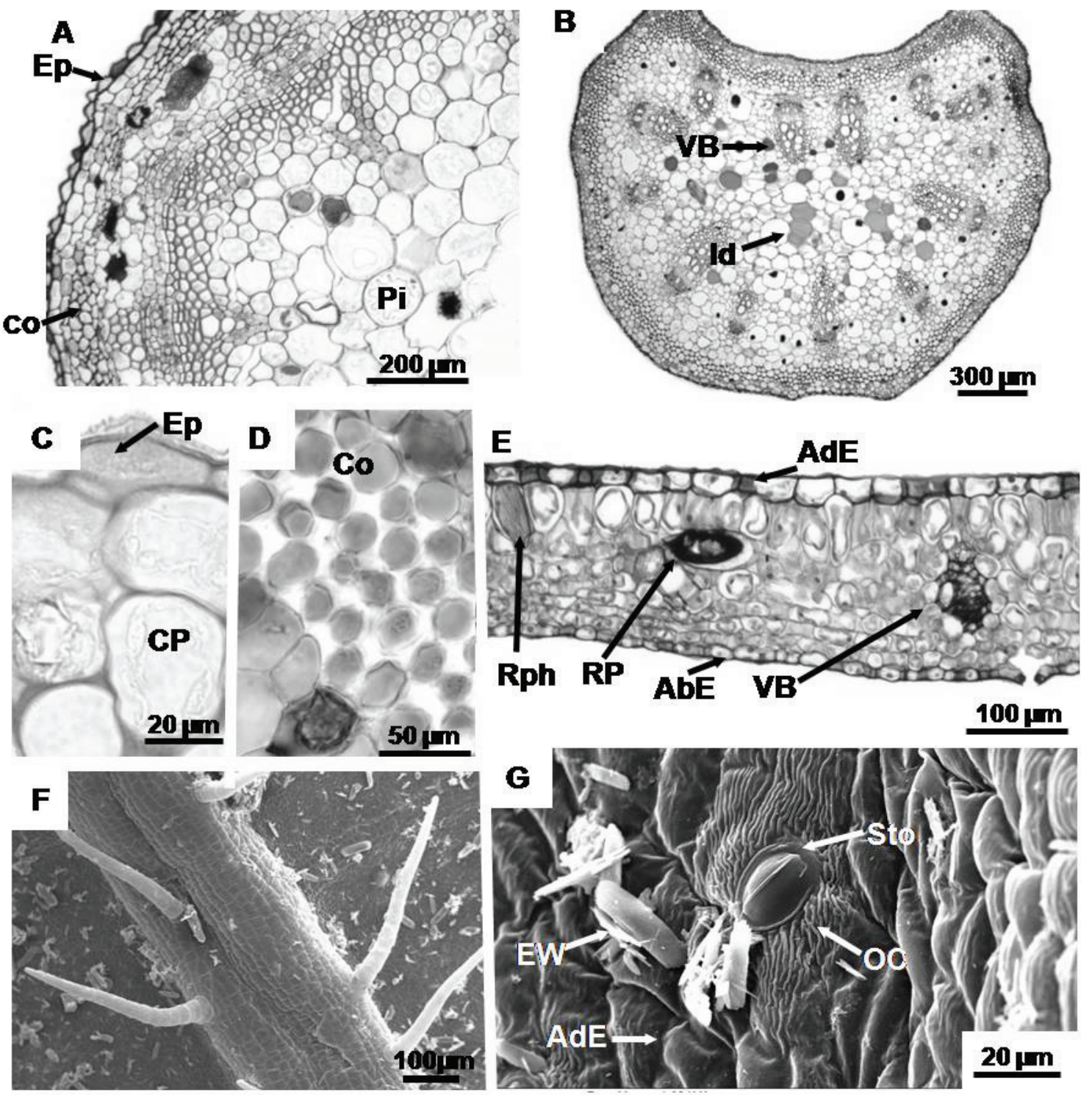

Figure 5. Cissus verticillata tendril, petiole and leaf lamina structure. (A-E: cross sections; F-G: MEV). A. general appearance of the tendril; B. petiole general aspect; C. details of the epidermis and the petiole subepidermal region; D. collenchyma; E. mesophyll; F. non-glandular trichomes midrib; G. leaf lamina adaxial surface. (Co, collenchyma; EW, epicuticular wax; OC, ornamented cuticle; AbE, abaxial surface of epidermis; AdE, adaxial surface of epidermis; Ep, epidermis with ornamented cuticle; Sto, stomata; VB, vascular bundle; Id, idioblast; Pi, pith; CP, chlorophyll parenchyma; Rph, raphide; RP, raphide and polysaccharide). 
surface of epidermis, while on the abaxial one, the collenchyma is annular with about four layers (Figure 6A, 6C).

The vascular bundles are collateral, and in the midrib they are organized in groups of seven, surrounded by a parenchyma sheath (Figure 6A). Crystalliferous idioblasts are located near the vascular bundles and sporadically in the mesophyll. Idioblasts with polysaccharide content, phenolic compounds (specifically tannin), lipids, essential oils and starch (Figure 6D-I) are observed in the parenchyma packing cells. The total protein detection test gave a negative reaction.
The total polysaccharides detected in the vegetative organs of $C$. verticillata were evidenced in the cytoplasm for both the solitary idioblasts and those containing raphides. These cells are widely distributed in all organs of the species.

\section{Discussion}

The presence of protostele and adventitious roots in the same individual of Cissus verticillata (L.) Nicolson $\&$ C.E. Jarvis, Vitaceae, is due to the type of vegetative propagation since it also propagates from cuttings. The
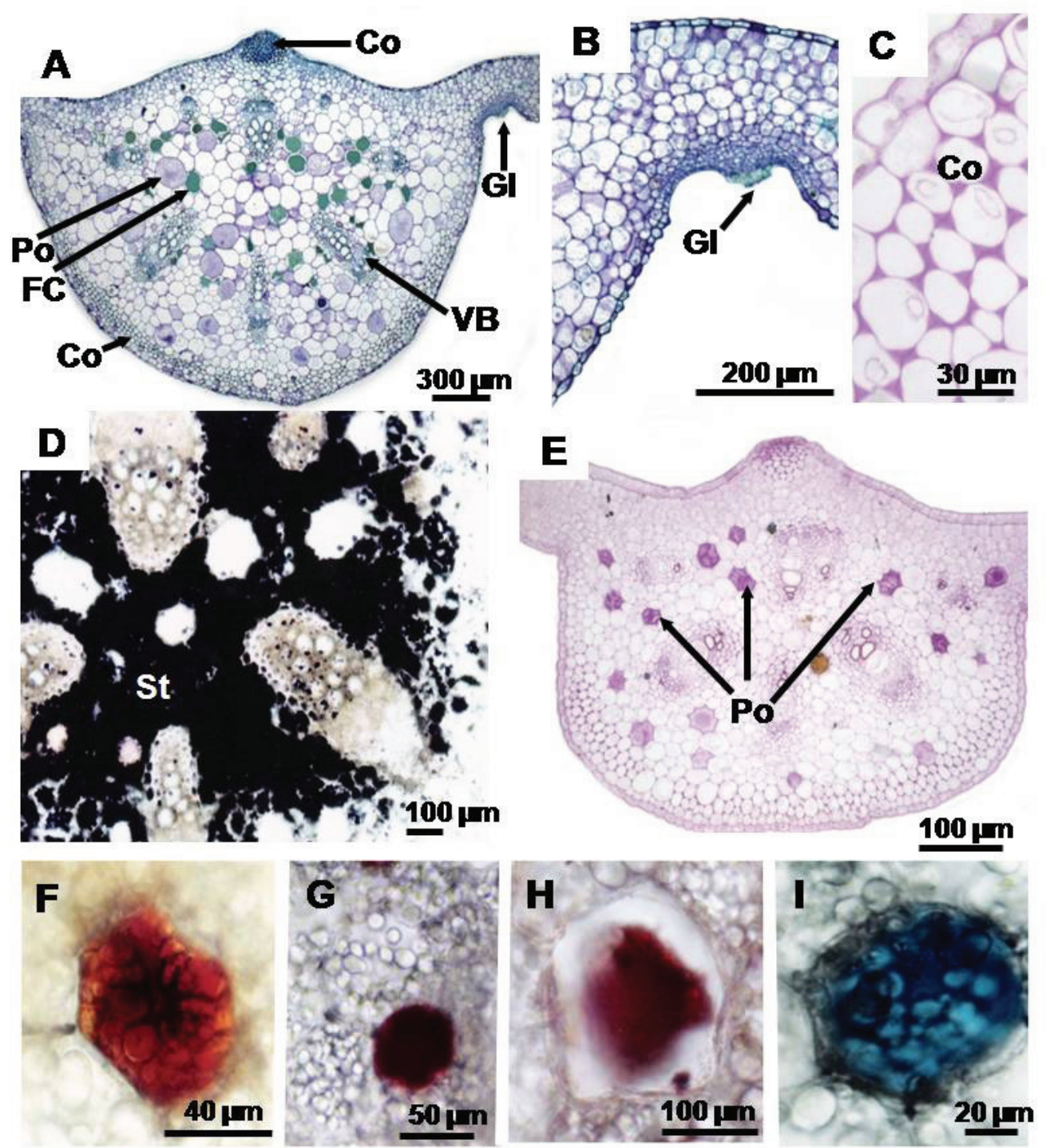

Figure 6. Cissus verticillata midrib structures. (A-I: cross sections). A. general aspect; B. gland on the abaxial surface; C. collenchyma; D. starch evidenced by the Lugol's iodine solution; E. idoblasts with polysaccharide evidenced by the PAS; F. idioblast with phenolic compound evidenced by the potassium dichromate, G. idioblast with tannin evidenced by the vanillin hydrochroride; H. idioblast with lipid evidenced by the Sudan IV; I. idioblast with essential oil evidenced by the Nadi. (St, starch; Co, collenchyma; PC, phenolic compound; VB, vascular bundle; Gl, gland; Po, polysaccharide). 
adventitious roots can develop from roots, hypocotyl of young plants, primary and secondary stem structure, and the leaf (Fahn, 1990). So, the vegetative propagation seemed be the best manner to grow the $C$. verticillata species which is used as medicinal propose.

Tylosis and cells releasing mixed substances were observed in $C$. verticillata stem. The occurrence of tylosis may be a natural event, though it appears to result from injuries, fungi attack, pathogens, or virus infection (Dickison, 2000). Another event that is related to the plant defenses is gummosis, in which amorphous polysaccharide or lipid substances contained in parenchyma cells groups are released and accumulated in a cavity formed by the disintegration of the secretory cells (Fahn, 1979), as appears to occur with $C$. verticillata. Gummosis may overcome the invasion of microorganisms or insects, by mechanical injury or physiological disturbances in the plant (Fahn, 1979).

The similar anatomical pattern between stem and tendril of C. verticillata, particularly related to the vascularization, suggests a common origin, as reported for Vitis species Vitaceae (Lorenzi, 2008). However, ontogenetic study is needed to confirm the origin of this organ.

Multicellular and uniseriate non-glandular trichomes and pearl glands were observed in the $C$. verticillata lamina. Non-glandular trichomes have already been reported for the Cissus species, however they are unicellular (Solereder, 1908; Metcalfe \& Chalk, 1957). The functions of the non-glandular trichomes vary according to their type and abundance, and the position in which they occur (Evert, 2006). In general, they protected plants from several external factors, such as herbivores and pathogens, excessive light, high temperatures, and excessive water loss, among others (Hallahan \& Gray, 2000). Pearl glands have already been described for $C$. verticillata (Paiva et al., 2009), as well as for other Vitaceae genera, as Leea and Vitis. This gland is denominated the food organ in $C$. verticillata, based on the morphological and functional aspects of this structure (Paiva et al., 2009). The cells that comprise these glands are rich in proteins, oils and sugars (Metcalfe \& Chalk, 1957; Paiva et al., 2009).

The crystalliferous idioblasts described for the C. verticillata vegetative organs are common in Vitaceae, as they are registered in other Cissus species and Vitis (Metcalfe \& Chalk, 1957). Different functions are assigned to these ergastic substances, such as mechanical defense from herbivores, structural support, calcium reserve, maintaining ionic balance, and metal and oxalic acid detoxification (Franceschi \& Horner, 1980; Volk et al., 2002; Franceschi \& Nakata, 2005).

The idioblasts with polysaccharide contents and phenolic compounds detected in the species studied are widely distributed in the parenchyma tissue of the stem of Leea angulata, Vitis vinifera, Cissus erosa and probably also in other Vitaceae species (Metcalfe \& Chalk, 1957; Alquini et al., 1995). Secretory cells can synthesize several substances, such as tannin, crystals, mucilage, essential oils, and resins, among others, which may be associated with the chemical defense mechanism of the plant (Fahn, 1990; Evert, 2006).

The histochemical results of the present paper indicate that the idioblasts are the site of mucilage synthesis and/or storage, as they reacted positively to the tests applied for polysaccharides. These results corroborate the chemical analyses of leaf strata of Cissus sicyoides (synonymy of Cissus verticillata) which detected mucilage (Abreu et al., 2002).

The mucilage and raphide accumulation in the interior of the idioblasts increases the pressure in the cell wall, causing it to rupture and facilitating the elimination of the crystal out of the cell (Evert, 2006; Franceschi \& Nakata, 2005). These structures are responsible for a toxic, non-beneficial effect in Dieffenbachia (Araceae), which was initially attributed to the presence of calcium oxalate crystals in the form of raphides (Arditti \& Rodriguez, 1982). However, further observation revealed that the crystals played a merely mechanical role, acting as penetrating agents, while the responsibility for the strongest toxic reaction, which causes contraction of the smooth musculature, was attributed to the action of protein compounds. Dip et al. (2004) also verified the toxic effect of Dieffenbachia picta caused by the presence of a lipophilic substance which surrounds calcium oxalate crystals.

The phenolic compounds and essential oil evidenced in the secretory idioblasts in $C$. verticillata are used in traditional medicine for the treatment of various diseases, such as general inflammation and hemorrhage (Simões et al., 2004).The population uses tea made from the vegetative parts of this species to treat these mentioned diseases (Oliveira, 2006).

In this context, Garcia et al. (2000) tested the anti-inflammatory effect, in laboratory mice, of the mixture of the aqueous stratum of $C$. sicyoides leaves and Agave intermixta, used in the popular medicine of the Caribbean. The authors obtained positives result for both species, A. intermixta being considered more efficient. Besides, Viana et al. (2004), testing the effectiveness of tea made from leaves of $C$. sicyoides, obtained a significant reduction in the levels of glucose, triglycerides and transaminase in the blood of mice with Diabetes mellitus type 2. The above authors comment that the polysaccharides are the compounds responsible for the glucose reduction, while flavonoids are responsible for the decrease of triglycerides and transaminases, justifying the use of this species as an alternative in the treatment of this disease. These data contribute to the bioprospecting of the C. verticillata 
species and also to emphasize the importance of the investigation on the medicinal plants.

\section{Conclusion}

The anatomical study of the vegetative organs of Cissus verticillata (L.) Nicolson \& C.E. Jarvis, Vitaceae, presents structural characters that are of use in the identification of the species, as the presence of the roots adventions, tendril, stomata of the anomocytic type and striated cuticle covering the stomatal complex cells and emphasizing the presence of the idioblast contend druses or raphides, and secretory idioblasts which may contend phenolic compounds, terpenoids or polysaccharides. These anatomical characters can be to use to identify medicinal plants and may be applicable to the quality control. The identification of the idioblasts as secretion sites of the compound reported as being responsible for the potential activity of the plant is of fundamental importance for future bioprospecting research on this species.

\section{Acknowledgements}

We thank the Microscopy and Microanalysis Center of the Federal University of Viçosa; the Federal University of Amazonas; CAPES and FAPEMIG for financial support; $\mathrm{CNPq}$ (Conselho Nacional de Pesquisa) for granting the scholarship (ABO) and for research fellowships (AAA and RMSAM); and Marcela Thadeo and Bruno Santana for their laboratory assistance.

\section{References}

Abreu LN, Pinto JEBP, Furtini Neto AE, Bertolucci SKV, Ladeira A, Geromel C 2002. Nitrogênio e fósforo na produção vegetal e na indução de mucilagem em plantas de insulina. Hortic Bras 20: 536-540.

Almeida ER, Oliveira JRG, Lucena FR, Soares RPF, Couto GBL 2006. The action of extract of the dry leaves of Cissussycioides L. in pregnant rats. Acta Farm Bonaer 25: 421-424.

Alquini Y, Bona C, Bueno NC, Cislinski J, Contin A, Dunaiski A, Segecin S 1995. Anatomia caulinar de quatro espécies do Gênero Cissus (Vitaceae), ocorrentes em Corumbá (MS)-Brasil. Braz Arch Bio Techn 38: 815827.

Arditti J, Rodriguez E 1982. Dieffenbachia: uses, abuses and toxic constituents: a review. $J$ Ethnopharmacol 5: 293302.

Barbosa WL, Santos WRA, Pinto LN, Tavares ICC 2002. Flavonóides de Cissus verticillata e a atividade hipoglicemiante do chá de suas folhas. Rev Bras Farmacogn 12: 13-15.

Beltrame FL, Sartoretto JL, Bazotte RB, Cuman RNE,
Cortez DAG 2001. Estudo fitoquímico e avaliação do potencial antidiabético de Cissus sicyoides L. (Vitaceae). Quim Nova 24: 783-785.

Berg MEVD 1993. Plantas medicinais da Amazônia: contribuição ao seu conhecimento sistemático. Belém: Museu Paraense Emílio Goeldi.

Bozzola JJ, Russel LD 1992. Eletronmicroscopy. Boston: Jones and Bartlett Publishers.

BragaTV 2008. Avaliação da atividade farmacológica de Cissusverticillata Nicolson\& C. E. Jarvissubsp. verticillata como antioxidante, antifúngico, hipoglicemiante e cicatrizante. Ouro Preto, 175 p. Dissertação de Mestrado, Programa de Pós-graduação em Ciências Farmacêuticas, Universidade Federal de Ouro Preto.

Brundett MC, Kendrick B, Peterson CA 1991. Efficient lipid staining in plant material with Sudan Red 7B or Fluoral Yellow 088 in polyethylene glycol-glycerol. Biotech Histochem 66: 111-116.

David R, Carde JP 1964. Coloration différentielle dês inclusions lipidique et terpeniques dês pseudophylles du Pin maritime au moyen du reactif Nadi. Comptes Rendus Hebdomadaires dês Séances de I'Academie dês Sciences Paris 258: 1338-1340.

Dickison WC 2000. Integrative plant anatomy. San Diego: Academic Press.

Dip EC, Pereira NA, Fernandes PD 2004. Ability of eugenol to reduce tongue edema induced by Dieffenbachia picta Schott in mice. Toxicon 43: 729-735.

Evert RF 2006. Esau's Plant anatomy: meristems, cells, and tissues of the plant body: their structure, function, and development. New Jersey: John Wiley \& Sons.

Fahn A 1979. Secretory tissues in plants. London: Academic Press.

Fahn A 1990. Plant Anatomy. Oxford: Pergamon Press.

Franceschi VR, Horner HTJr 1980. The botanical review. Botanic Garden 46: 361-427.

Franceschi VR, Nakata PA 2005. Calcium oxalate in plants: formation and function. Annu Rev Plant Biol 56: 4171.

Gabe M 1968. Techniques histologiques. Paris: Masson \& Cie.

Garcia AM, Quílez MT, Saenz ME, Martinez-Dominguez RP 2000. Anti-inflammatory activity of Agave intermixta Trel. and Cissussicyoides L., species used in the Caribbean traditional medicine. J Ethnopharmacol 71: 395-400.

Garcia X, Heredia-Cartas L, Jímenez-Lorenzana ME, Gijón E 1997. Vasoconstrictor effect of Cissussicioydes on guinea-pig aortic rings. Gen Pharmacol 29: 457-462.

Hallahn DL, Gray JC 2000. Plant trichomes. San Diego: Academic press.

Howard RA 1979. The petiole. In Metcalfe CR, Chalk L. Anatomy of the dicotyledons. Oxford: Clarendon Press, p. 88-96. 
Jensen WA 1962. Botanical histochemistry: principles and practice. San Francisco: W. H. Freeman \& Co.

Johansen DA 1940. Plant microtechnique. New York: McGraw-Hill.

Kraus JE, Arduin M 1997. Manual básico de métodos em morfologia vegetal. Rio de Janeiro: Edur.

Lizama RS, Martinez MM, Pèrez OC 2000. Contribución al estúdio de Cissus sicioydes L. (Bejuco-ubí). Rev Cubana Farm 34: 120-124.

Lombardi JA 2007. Systematics of Vitaceae in South America. Can J Bot 85: 712-721.

Lorenzi H 2008. Plantas medicinais no Brasil: nativas e exóticas. São Paulo: InstitutoPlantarum.

Mace ME, Howell CR 1974. Histological and histochemical uses of periodic acid. Stain Tech 23: 99-108.

Maia V 1979. Técnica Histológica. São Paulo: Atheneu.

Metcalfe CR, Chalk L 1957. Anatomy of the dicotyledons. Oxford: Clarendon Press.

Metcalfe CR, Chalk L 1979. Anatomy of the dicotyledons. Oxford: Clarendon Press.

O' Brien TP, Mccully ME 1981. The study of structure principles and selected methods. Melbourn: termarcarphi Pty. LTD.

Oliveira AB 2006. Cissus verticillata (Vitaceae): Informações etnofarmacológicas e anatomia dos órgãos vegetativos. Viçosa, 72p. Dissertação de Mestrado, Programa de Pós-graduação em Botânica, Universidade Federal de Viçosa.

Paiva EAS, Buono FA, Lombardi JA 2009. Food bodies in Cissus verticillata (Vitaceae): ontogenesis, structure and functional aspects. Ann Bot 103: 517-524.

Pepato MT, Baviera AM, Vendramine RC, Perez MPMS, Kettelhutt IC, Brunetti IL 2003. Cissus sicyoides (princess vine) in the long-term treatment of streptozotocin-diabetic rats. Biotechnol Appl Bioc 37: 15-20.

Silva L, Onik GH, Agripino DG, Moreno PRH, Young MCM, Mayworm MAS, Ladeira AM 2007. Biciclogermacremo, resveratrol e atividade antifúngica em extratos de folhas de Cissus verticillata (L.) Nicolson \& Jarvis (Vitaceae). Rev Bras Farmacogn 17: 361-367.

Simões CMO, Schenkel EP, Gosmann G, Mello JCP, Mentz LA, Petrovick PR 2004. Farmacognosia: da planta ao medicamento. Porto Alegre: Editora da UFRGS/ UFSC.

Solereder H 1908. Systematic anatomy of the dicotyledons. Oxford: Clarendon Press, p. 889-890.

Theobald WL, Krahulik JL, Rollins RC 1979. Trichome description and classification. In Metcalfe CR, Chalk L. Anatomy of the dicotyledons. Oxford: Clarendon Press, p. 40-53.

Viana GSB, Medeiros ACC, Lacerda AMR, Leal LKAM, Vale TG, Matos JA 2004. Hypoglycemic and anti-lipemic effects of the aqueous extract from Cissus sicyoides. Pharmacology 4: 1-14.

Volk GM, Holm VJL, Kostman TA, Goss LJ, Franceschi VR 2002. The role of druse and raphide calcium oxalate crystals in tissue calcium regulation in Pistia stratiotes leaves. Plant Biol 4: 34-45.

\section{*Correspondence}

Renata Maria Strozi Alves Meira

Plant Anatomy Laboratory, Federal University of Viçosa Avenida P. H. Rolfs s/n Campus Center, 36560-000 ViçosaMG, Brazil

rmeira@ufv.br

Tel. +55 3138992584 